\title{
THE EFFECT OF BOOKLET EDUCATION ABOUT CHILDREN NUTRITION NEEDS TOWARD KNOWLEDGE OF MOTHER WITH STUNTING CHILDREN IN PUNDONG PRIMARY HEALTH CENTER WORK AREA BANTUL YOGYAKARTA
}

\author{
Suryati ${ }^{1}$, Supriyadi ${ }^{2)}$ \\ STIKes Surya Global Yogyakarta \\ Corresponding e-mail : suryatisakha11@gmail.com
}

\begin{abstract}
BACKGROUND : Stunting defined as chronic malnutrition during infancy, that cause height-for-age $z$ score (HAZ) <-2 SD. Children with stunting, has been related to poor cognitive function in late childhood motoric ability, productivity and increasing the risk of degenerative desease in the future. Nutritional problem in children associated with some related factor, one of the factor is lack of knowledge about children nutrition needs. One of the Indonesian governance preventive action on increasing the mother with stunted children knowledge about nutrition needs is a health promotion. This study was aimed to examine the effect of booklet education about children nutrition needs toward knowledge of mother with stunted children.
\end{abstract}

SUBJECT AND METHODE : Quasi-experimental with non equivalent control group with pretest and posttest was used, 90 mother with stunted children was recruited with simple random sampling. Wilcoxon and Mann Whitney analysis was performed.

RESULTS : Based on Wilcoxon test results obtained mother knowledge was significantly increased $(p<0.05)$ after the intervention, from $29(64 \%)$ was categorized as fair knowledge, increased to 34 (75.6\%) categorized as good knowledge after the intervention. Mann Whitney test results showed that mother knowledge improvement in intervention and control group was significantly different $(p<0.05)$.

DISCUSSION : there is an influence of booklet education on the knowledge of mothers of toddlers with stunting

Keywords: mother knowledge, stunting, booklet

\section{INTRODUCTION}

Stunting is a condition where a toddler has a length or height that is less when compared to age. This condition is measured by length or height that is more than -2 standard deviations from the median standard of child growth from WHO. Toddler stunting includes chronic nutritional problems caused by many factors such as socioeconomic conditions, maternal nutrition during pregnancy, morbidity in infants, and lack of nutrition in infants. Stunting toddlers in the future will experience difficulties in achieving optimal physical and cognitive development (Kemenkes RI, 2018).

The prevalence of stunting in several countries in Southeast Asia, such as Myanmar by $35 \%$, Vietnam by $23 \%$, and Thailand by $16 \%$. The prevalence of stunting in Indonesia according to the 2013 Basic Health Research was 37.2 percent, an increase from 2010 which was $35.6 \%$ and in 2007 it was $36.8 \%$. 
Toddlers who experience nutritional problems increase the risk of decreased intellectual ability, inhibit motor skills, productivity, and increase the risk of degenerative diseases in the future. Nutrition problems in infants can be caused by several factors, including low family income, habits that are believed by mothers, and low nutritional knowledge in mothers or caregivers (Shi, et al., 2011, Susanty, 2011; Kulwa, et al., 2014 ).

In the study of Rajan, et al., 2015 on nutritional knowledge, showed that out of 130 mothers $(65 \%)$ had average knowledge, 60 mothers $(30 \%)$ had poor knowledge and only 10 mothers $(5 \%)$ had good knowledge about nutrition. Low maternal knowledge about nutrition can lead to poor food intake, type and quality, so the incidence of acute malnutrition can increase significantly. (Ambadekar, et al., 2016).

According to Negash, et al., 2014 explained that nutrition knowledge is an individual's understanding of nutrition, including the ability to remember related to information related to nutrition.

One factor that influences knowledge about nutrition is exposure to information sources. Advances in technology provide a variety of media that can influence public knowledge about new information, such as television, radio, newspapers, magazines, counseling, and others. (Yuliana, 2017). One of the efforts made by the government in increasing the knowledge of mothers with stunting toddlers is by providing health education (Ministry of Health Republic of Indonesia, 2011).

Booklet is a media for delivering health messages in the form of books with a combination of writing and pictures. The strengths of the booklet media are information that is more complete, more detailed and clear and is educative. In addition, the booklet that is used as an educational medium can be brought home, so that it can be read over and over again and stored. This is the reason for the selection of booklets as educational media.

This study aims to determine the effect of nutrition education by using a media booklet on maternal knowledge about nutrition in stunting toddlers in the working area of Pundong Bantul Public Health Center in Yogyakarta. Based on some of the considerations above, researchers are interested in examining whether health education using a media booklet about meeting nutritional needs in toddlers with stunting can provide solutions related to problems faced by parents with stunting children.

\section{METHODS}

This study using a quasi- experimental, non-equivalent control group design with pretest and post test (Notoatmodjo, 2010, Sastroasmoro, 2011). The sample in this study was mothers of stunting toddlers with a total of 90 respondents, which were divided into two groups, intervention and control groups. The intervention group get education using the lecture method and booklet media, while the control group get education using the lecture method without being given a booklet. The sampling technique uses simple random sampling. Analysis of research data using the Wilcoxon statistical test with a significance level of $95 \%$, to determine the difference in knowledge between pretest and posttest. The instrument in this study used a mothers knowledge 
questionnaire about toddler nutrition. Mann Whitney statistical test to see differences in the posttest value of respondents' knowledge in the intervention and control groups.

\section{RESULT AND DISCUSSION}

The results of this study present the characteristics of respondents, knowledge before and after the intervention and control groups, as well as differences in posttest knowledge in the intervention and control groups. Data on the characteristics of respondents can be seen in table 1 below:

Table 1. Characteristics of Respondents in the Pundong Public Health Center Work Area Bantul Yogyakarta

\begin{tabular}{|c|c|c|c|c|}
\hline \multirow[t]{2}{*}{ Characteristic } & \multicolumn{2}{|c|}{$\begin{array}{c}\text { Intervention Group } \\
(n=45)\end{array}$} & \multicolumn{2}{|c|}{ Control Group $(n=45)$} \\
\hline & $\mathbf{n}$ & $\%$ & $\mathbf{n}$ & $\%$ \\
\hline \multicolumn{5}{|l|}{ Mother's age (years old) } \\
\hline $20-24$ & 6 & 13,3 & 3 & 6,7 \\
\hline $25-29$ & 15 & 33,3 & 14 & 31,1 \\
\hline $30-34$ & 11 & 24,4 & 11 & 24,4 \\
\hline $35-39$ & 4 & 8,9 & 7 & 15,6 \\
\hline $40-44$ & 9 & 20,0 & 10 & 22,2 \\
\hline \multicolumn{5}{|l|}{ Mothers Educational Level } \\
\hline Uneducated & 3 & 6,7 & 0 & 0 \\
\hline Elementary School & 10 & 22,2 & 13 & 28,9 \\
\hline Junior High School & 8 & 17,8 & 11 & 24,4 \\
\hline Senior High School & 20 & 44,4 & 20 & 44,4 \\
\hline Bachelor Degree & 4 & 8,9 & 1 & 2,2 \\
\hline \multicolumn{5}{|l|}{ Number of Family Member } \\
\hline$>4$ & 34 & 75,6 & 30 & 66,7 \\
\hline$<4$ & 11 & 24,4 & 15 & 33,4 \\
\hline \multicolumn{5}{|l|}{ Occupation } \\
\hline Farmer & 2 & 4,4 & 5 & 11,1 \\
\hline Laborer & 6 & 13,3 & 8 & 17,8 \\
\hline Trader & 3 & 6,7 & 7 & 15,6 \\
\hline Private Employee & 3 & 6,7 & 4 & 8,9 \\
\hline House Wife & 31 & 68,9 & 21 & 46,7 \\
\hline \multicolumn{5}{|l|}{ Family Income : } \\
\hline$\geq$ City Minimum Wage (CMW) & 11 & 24,4 & 16 & 35,6 \\
\hline$<$ City Minimum Wage (CMW) & 34 & 75,6 & 29 & 64,4 \\
\hline \multicolumn{5}{|c|}{ Culture in Providing the nutritional needs of toddlers } \\
\hline Exist & 4 & 8,9 & 9 & 20,0 \\
\hline Doesn't Exist & 41 & 91,1 & 36 & 80,0 \\
\hline 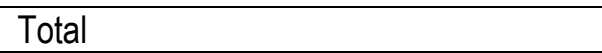 & 45 & 100 & 45 & 100 \\
\hline \multicolumn{5}{|c|}{$\begin{array}{l}\text { Based on table 1, it can be seen that the characteristics of the respondents in the } \\
\text { ntervention group and the control group are not much different, this can be seen from the }\end{array}$} \\
\hline
\end{tabular}


is less tha city minimum wage, and most respondents have no certain culture in providing the nutritional needs of toddler in the control and intervention groups.

Table 2. Mother's Knowledge Before and After Educational Booklets Are Given To Intervention Groups

\begin{tabular}{llccccc}
\hline & & $\mathrm{n}$ & $\%$ & $\begin{array}{c}\text { Mean } \\
\text { Rank }\end{array}$ & $\mathrm{Z}$ & p-value \\
\hline Intervention & Negative & 3 & 6.7 & 4.17 & -5.496 & 0.000 \\
Group & Positive & 39 & 86.6 & 22.83 & & \\
& Ties & 3 & 6.7 & & & \\
& Total & 45 & 100 & & & \\
\hline
\end{tabular}

Based on table 2, the results obtained by respondents who have a posttest value greater than the pretest value of 39 respondents $(86.6 \%), 3$ respondents $(6.7 \%)$ increase impairment and contain 3 respondents $(6.7 \%)$ who do not has a change in value. Can increase the value that occurs with a posstest value higher than the pretest value. Also obtained $p$-value $<a(0.05)$, the conclusion can be drawn so that $\mathrm{Ho}$ is rejected, it can be interpreted as difference in the pretest feedback score with the posttest intervention group.

Table 3. Mother's Toddler's Knowledge Before and After Providing Educational Lectures (Without Booklets) to the Control Group

\begin{tabular}{llccccc}
\hline & & $\mathrm{n}$ & $\%$ & Mean Rank & $\mathrm{Z}$ & $\mathrm{p}$-value \\
\hline Control & Negative & 21 & 46.7 & 21.71 & -1.586 & 0.113 \\
Group & Positive & 16 & 35.6 & 15.44 & & \\
& Ties & 8 & 17.7 & & & \\
& Total & 45 & 100 & & & \\
\hline
\end{tabular}

Based on table 3, the results show that respondents who have a posttest value greater than the pretest value of 16 respondents (35.6\%), 21 respondents $(46.7 \%)$ experienced a decrease in value and there were 8 respondents $(17.7 \%)$ who has no change in value. It can be concluded that the majority of respondents did not experience an increase in knowledge. Also obtained $p$ value $>\mathrm{a}(0.05)$, it can be concluded that $\mathrm{Ho}$ is accepted, or it can be interpreted that there is no difference in the assessment of knowledge both pretest and posttest in the control group. The results of the pretest and posttest knowledge of mothers in the intervention group who were given booklet education showed a statistically significant increase with a $p$ value of $0.001(p<0.05)$. This means that booklet education as a medium in providing education has proven to be effective in increasing mothers' knowledge about the nutritional needs of children under five. Pretest and posttest were conducted to see the difference between the knowledge of mothers who received education with the media booklet and education with the lecture method.

The results showed there were more significant differences in knowledge in the intervention group compared to the control group. This is in line with the results of the study of Setyawati \& Herlambang, 2015 that there were differences in knowledge in the treatment and control groups and there was a statistically significant increase in the treatment group $(p=0,0001)$. The same thing was stated by the research of Wulansari, et al, 2019 where there were significant differences between knowledge before and after health education was given with a media booklet with a $p$-value of $0,000<0.05$. Most respondents have higher posttest scores than pretest scores. 
Changes in increased knowledge were higher in the intervention group who were given education by the media booklet compared to the control group that was given education by the lecture method. This can be caused by the distribution of the booklet as an ingredient in discussing matters that would be a problem for mothers of toddlers in meeting the nutritional needs of toddlers. With increasing knowledge about the nutritional needs of toddlers will be more likely to recognize stunting prevention in toddlers. This is in line with the statement made by Wahyudi, et al. (2015) that if the community's knowledge about nutrition is lacking, then the public does not pay attention to good food intake so that the nutritional status of children under five becomes even worse. Conversely, if the public knowledge is good, the community will be better able to manage and prepare nutritious food menus to meet the nutritional status of their children.

Tabel 4. Mean Difference Analysis Posttest Value of Mother's Toddler Knowledge In the Intervention and Control Groups

\begin{tabular}{cccc}
\hline Posttest Knowledge & Mean Rank & Z & p-value \\
Intrevention Group & 57,92 & $-4,530$ & 0,000 \\
Control Group & 33,08 & & \\
\hline
\end{tabular}

Table 4 shows the mean rank of knowledge of the intervention group respondents was 57.92 while the mean rank of knowledge of the control group respondents was 33.08 . There is a difference of 24.84 points, statistically obtained $p$ value $=0,000$ which means $p$ - value $<a=0.05$, it can be concluded that $\mathrm{Ho}$ is rejected or it can be interpreted that there is a significant difference in knowledge between the two groups at the posttest, where the group the intervention had higher knowledge than the control group.

The results of the pretest and posttest knowledge of mothers in the intervention group who were given booklet education showed a statistically significant increase with a $p$ value of 0.001 ( $p$ $<0.05$ ). This means that booklet education as a medium in providing education has proven to be effective in increasing mothers' knowledge about the nutritional needs of children under five. Pretest and posttest were conducted to see the difference between the knowledge of mothers who received education with the media booklet and education with the lecture method.

The results showed there were more significant differences in knowledge in the intervention group compared to the control group. This is in line with the results of the study of Setyawati \& Herlambang, 2015 that there were differences in knowledge in the treatment and control groups and there was a statistically significant increase in the treatment group $(p=0,0001)$. The same thing was stated by the research of Wulansari, et al, 2019 where there were significant differences between knowledge before and after health education was given with a media booklet with a $p$-value of $0,000<0.05$. Most respondents have higher posttest scores than pretest scores.

Changes in increased knowledge were higher in the intervention group who were given education by the media booklet compared to the control group that was given education by the lecture method. This can be caused by the distribution of the booklet as an ingredient in discussing matters that would be a problem for mothers of toddlers in meeting the nutritional needs of toddlers. With increasing knowledge about the nutritional needs of toddlers will be more likely to recognize stunting prevention in toddlers. This is in line with the statement made by Wahyudi, et al. (2015) that if the community's knowledge about nutrition is lacking, then the public does not pay attention to good food intake so that the nutritional status of children under five becomes even worse. 
Conversely, if the public knowledge is good, the community will be better able to manage and prepare nutritious food menus to meet the nutritional status of their children.

Pretest and posttest were conducted to see the difference in knowledge of mothers who received education by the booklet method. The results showed there were significant differences in knowledge before and after the booklet education was given. This is in line with research conducted by Pratiwi and Puspitasari, 2017 which revealed that there is an influence of booklet education on the knowledge of toddlers, this is evidenced by the significant difference in the value of knowledge $(p=0.001)$, before and after booklet education. Increased maternal knowledge is an influence of booklet education and is not influenced by other factors such as respondent characteristics.

This is supported by data that the characteristics of respondents (age, level of education, occupation, number of family members, family income, and cultural factors) in this study did not differ significantly in the intervention group or the control group. This is in line with the statement of Setyawati \& Herlambang, 2015 where if the characteristics of the respondents of the two groups did not differ significantly, then this could meet the matching requirements for an experimental study. In this study, the majority of mothers of children under five have a high school education level. The results of the intervention group and the control group pretest were not much different, where most of the respondents' knowledge was in the sufficient category. According to Arbella's (2013) research a person's level of education can determine the person's way of thinking. This is because respondents with higher education tend to have broader insights than respondents with low education.

\section{CONCLUSION AND RECOMMENDATION}

Before the intervention was given as many as 9 respondents (20\%) less category, 29 respondents $(64.5 \%)$ had enough knowledge in the category, 7 respondents $(15.5 \%)$ good category. After intervention, 34 respondents $(75.6 \%)$ had knowledge in the good category, 8 respondents (17.7) in the sufficient category, and 3 respondents (6.7) in the poor category. Thus it can be concluded that there is an influence of booklet education on the knowledge of mothers of toddlers with stunting.

Education and health promotion about the nutritional needs of toddler can be done more routinely in the working area of Pundong Health Center as a first step in reducing the number of stunted children. The need for other research to develop educational interventions using media other than booklets and the development of research variables other than knowledge, such as the attitudes and behaviors of mothers about the nutritional needs of children under five.

\section{REFERENCES}

Ambadekar, N.N. \& Zodpey, S.P., (2016). Risk factors for severe acute malnutrition in under-five children: a case-control study in a rural part of India.. Public Health 
Journal.Tersedia di https://www.ncbi.nlm.nih.gov/pubmed/27613225

Arbella, V.M. (2013). Hubungan Pengetahuan Dan Sikap Ibu Tentang Keluarga Sadar Gizi Dengan Perilaku Sadar Gizi Keluarga Balita Di Desa Karangsono Kecamatan Kwadungan Kabupaten Ngawi tahun 2013. Jurnal Kebidanan 2(5), 47-56.

Kementrian Kesehatan RI No: 1995/MENKES/SK/XII/2010. 2011). Standar Antropometri Penilaian Status Gizi Anak. Direktorat Jenderal Bina Gizi Dan Kesehatan Ibu Dan Anak.

Kementrian Kesehatan RI. (2013). Riset kesehatan dasar: riskesdas 2013. Jakarta: Kementrian Kesehatan RI \& Bakti Husada.

Kulwa, Kissa., Verstraeten, Roosmarijn., Bouckaert, Kimberley., Mamiro, Peter., Kolsteren,P., Lachat C. (2014). Effectiveness of a nutrition education package in improving feeding practices, dietary adequacy and growth of infants and young children in rural Tanzania: rationale, design and methods of a cluster randomised trial. BMC Public Health 2014, 14:1077. http://www.biomedcentral.com/14712458/14/1077.

Negash, C. (2014). Nutrition Education And Introduction Of Broad Bean - Based Complementary Food Improves Knowledge And Dietary Practices Of Caregivers And Nutritional Status Of Their Young Children In Hula, Ethiopia. Sage Journals. Tersedia di http://journals.sagepub.com/doi/abs/10.1177/156482651403500409?url ver= Z39.88-2003\&rfr_id=ori:;id:Crossref.org\&rfr_ dat=cr_pub\%3dpubmed

Notoatmodjo, S. (2010). Metodologi Penelitian Kesehatan. Jakarta PT Rineka Cipta.

Pratiwi, Y.F. \& Puspitasari, D.I. (2017). Efektivitas Penggunaan Media Booklet Terhadap Pengetahuan Gizi Seimbang Pada Ibu Balita Gizi Kurang Di Kelurahan Semanggi Kecamatan Pasar Kliwon Kota Surakarta. Jurnal Kesehatan, Issn 1979-7621, Vol. 10, No. 1. Juni 2017

Pusat Data dan Informasi, Kementerian Kesehatan RI. (2018). Situasi Balita Pendek (Stunting) di Indonesia. Buletin Jendela Data dan Informasi Kesehatan. ISSN 2088 - 270 X

Sastroasmoro, S dan Ismael, S. (2011). Dasar-dasar Metodologi Penelitian Klinis. Binarupa Aksara: Jakarta.

Setyawati, V.A.V.,Herlambang, B.A., (2015). Model Edukasi Gizi Berbasis E-Booklet Untuk Meningkatkan Pengetahuan Gizi lbu Balita.

Shi, L., Zhang, J., Wang, Y., Caulfield, L. E., \& Guyer, B. (2010). Effectiveness of an educational intervention on complementary feeding practices and growth in rural China: a cluster randomised controlled trial. Public Health Nutrition Journal. Tersedia di http://doi.org/10.1017/S13689800099 91364 
Susanty, Mery. (2011). Hubungan Perilaku tentang Pencegahan Malnutrisi dengan Kejadian Gizi Buruk di Desa Bukit Padi Kecamatan Jemaja Kabupaten Natuna T. PSIKM FK Unand: Padang.

Wahyudi, B.F., Sriyono, Indarwati, R. (2015). Analisis Faktor Yang Berkaitan Dengan Kasus Gizi Buruk Pada Balita. Jurnal Pediomaternal. Vol. 3 No. 1 Oktober 2014-April 2015

Wulansari, R.M., Corniawati, I., Utami, K.D. (2019). Efektivitas Model Edukasi Booklet Terhadap Pengetahuan Gizi Pada Ibu Balita Di Wilayah Kerja Puskesmas Harapan Baru Kota Samarinda. Poltekkes Kemenkes Kalimantan Timur

Yuliana, Erlin. (2017). Analisis Pengetahuan Siswa Tentang Makanan Yang Sehat dan Bergizi Terhadap Pemilihan Jajanan di Sekolah. Universitas Muhammadiyah Purwokerto. 